\title{
Ideologization of Translation History: The Case of Russian Democrats and Aesthetes
}

\author{
Andrei V. Achkasov* \\ Herzen State Pedagogical University of Russia, \\ 48 Moyka Embankment, St. Petersburg, 191186, Russia
}

Received 29.09.2018, received in revised form 10.10.2018, accepted 16.10.2018

One of the pivotal themes of the Soviet translation school in the 1930-1960s was the 'false' principals of formalism and literalism and the promotion of realistic translation. The article shows that this discussion was retrospectively "transposed" onto the 19th-century literary translation and entailed the ideologization of the translation history. As a result, the 19thcentury translation practices were conceptualized as a confrontation of aesthetic (reactionist) and democratic (revolutionary) translation "camps" that were guided respectively by "false" and "correct" translation principles. Soviet studies on the history of Russian literary translations recognize this approach as the only true one, and relate the achievements of the Russian translation of this mid-19th century to the work of translators of the "revolutionary democratic camp" and the "democratic" translation criticism. Within the framework of this ideologically biased approach much effort was also put into finding the 19th century predecessors of realistic translation, a counterpart of socialist realism. According to this interpretation various 19th century translators were declared as the precursors of the Soviet "realistic translation". This approach resulted in creating a model of the development of translation that follows the "classicism - romanticism - realism" pattern typically used in the Soviet literary criticism. Researchers offered various interpretations of the notions of "romantic" and "realistic" translation, and this opposition found meaning in the contrast between "false" and "correct" principles employed by translators from the democratic and aesthetic ideologies. It is shown in the article that this trend was consistent with the ideological paradigm of socialist literary theory and the interpretation of the history of art in general.

Keywords: translation history, ideologization, Soviet translation school, literalism realistic translation, democrats, aesthetes.

Research area: philology.

Citation: Achkasov, A.V. (2018). Ideologization of Translation History: The Case of Russian Democrats and Aesthetes. J. Sib. Fed. Univ. Humanit. soc. sci., 11(10), 1532-1546. DOI: 10.17516/1997-1370-0320.

(C) Siberian Federal University. All rights reserved

* Corresponding author E-mail address: a_v_achkasov@mail.ru

This work is licensed under a Creative Commons Attribution-NonCommercial 4.0 International License (CC BY-NC 4.0) 


\section{Introduction}

Ideological underpinnings of the Soviet school of translation have been addressed in seminal works by S. Witt (Witt, 2017; Witt, 2016), B. J. Baer (Baer, 2016), S. Witt and B. J. Baer (2017), S. Sherry (Sherry, 2015), A. Azov (2013). This complex issue has been studied in various aspects, including "ideologization of norms" (Witt, 2013), practices of indirect literary translation (Witt, 2017), the role of publishing politics in establishing ideological trends in literary translation (Khomitsky, 2013), the impact of socialist realism and publishing practices on the translation of children's literature (Inggs, 2015), etc. The pivotal theme in the discussion of the ideology of the Soviet translation school is the application of principles of socialist realism to translation theory and practice. The debate on translation in the 1930-1960s was embedded within the literary processes and the discussion on the principles of socialist art in general and its "struggle" against "formalism" and "naturalism". Starting from the end of the 1930 s, the terms "formalism" and "naturalism" were used to characterize translation thus forming the core of a new translation ideology: "A bad translator, the one who pays close attention to the shades of the meaning of each word of the original, is a naturalist. A bad translator, the one who reproduces unusual stylistic or poetic techniques of the original is a formalist. $<\ldots>$ On the value axis of Soviet criticism, the opposite of naturalism and formalism was socialist realism. It is therefore quite natural that a good translator was eventually proclaimed a realist translator, and a good method of literary translation was proclaimed a realistic method" (Azov, 2013: 42).

This ideological paradigm has been examined in relation to $20^{\text {th }}$ century translations. However, one aspect of the twentieth-century "Soviet translation ideology" (Witt, 143) remains understudied. The campaign against formalism and literalism (bukvalizm) and the promotion of realistic translation (realisticheskii perevod), the pivot of the Soviet translation ideology, was retrospectively "transposed" onto the $19^{\text {th }}$-century literary translation and entailed the ideologization of the $19^{\text {th }}$-century debates on translation principles and practices. During the $1930-1960$ s, $19^{\text {th }}$-century translation practices were conceptualized as a confrontation of aesthetic (reactionist) and democratic (revolutionary) translation "camps" and much effort was put into finding the predecessors of realistic translation. These attempts were in line with the major trends of socialist literary ideology and the interpretation of the history of art in general.

In the 1920s and the beginning of the 1930s, the practice of rendering formal features of the source text was generally conceptualized as a positive trend. Moreover, as opposed to the low-quality "mass translations" (massovye perevody) of the end of the 
$19^{\text {th }}$ century, the focus on various aspects of the "form" of the original was recognized the state of the art of translation practice. Later on, Chukovsky characterized this practice with a certain amount of dispraise: "It was at that time (in the 1920s and 1930s) that a fetishist attitude to the so-called equilinearity (ekvilinearnost) and equirhythmism (ekviritmiya) in verse translations gained a footing. A strict requirement was put forward, demanding that every translated poem, be a tragedy or a love romance, should contain a number of lines equal to those of the original, and that the rhythm of each line of the translation should correspond to the rhythm of the same original line. This claim, in itself, was highly useful: it marked the end of that loose highhandedness that unrestrictedly prevailed in translations of the past era" (Chukovsky, 1988:185).

Formalism in translation, generally interpreted as a method to create an "authentic" Russian version of a foreign author's text, was generally regarded as a progressive technique. This was the reason why, for instance, Anna Radlova's translations were such a success - they were always favourably reviewed, and Literaturnaia entsiklopediia [Literary encyclopedia] called them masterpieces in the 1930s. In general, researchers of the 1920s and 1930s tend to be critical about the desire to reduce distinctive features of the original to "elementary intonations" (Chukovsky), to erase the signs of "foreignness" in translations via stylistic adaptation, to the use of elements that "adapt" the original for a new language environment ("wrapping material", as A. Fedorov put it), and about the modernization of translations. This kind of criticism was often expressed in the analysis of translations of the mid- $19^{\text {th }}$ century.

In this context, the so-called literal translations of the $19^{\text {th }}$ century generally received positive reviews. Even Afanasy Fet's translation principles seemed to formally correlate with the general course of the development of the translation of literary works into Russian and with the overall development of translation thought, even though later Fet was classified as the most radical literalist of the mid-19 $19^{\text {th }}$ century. His translations were positively reviewed by Viktor Zhirmunsky (who was especially enthusiastic about Fet's translations of poetry) and Korney Chukovsky. The latter even praised Fet's translation of Julius Caesar (which was pretty much unheard of in Russian translation studies) and sharply criticized translators who downplayed and softened Shakespeare's metaphors: "Translators clearly do not like the fact that the phraseology of Shakespeare's plays is ripe with metaphors that may seem extravagant, wild, frantic and sometimes even monstrously ugly to an unaccustomed reader. Many see it as a vice - not unlike drinking or fornication - and they try to wash this filth from Shakespeare's works via their translations" (Chukovsky, 1936: 167). Fedorov expresses 
similar thoughts touching on issues of phonetics and poetry. In his article "The sound form in verse translation" he essentially frames one of the theses of literalism in 20thcentury terms: "The tasks that a translator sets for himself may be different: along with the intention to create a functionally adequate form, another intention may come into play - to give a foreign ring to a translation, to use foreign metric techniques, or at least a desire to leave a hint of such techniques" (Fedorov, 1928: 53).

At the same time, Russian translation studies of the 1930s see the development of stereotypical ideas about the state and evolution of the Russian translation culture in the mid-1 $19^{\text {th }}$ century. These stereotypes are primarily connected with the ideological opposition of "aesthetic" (reactionist) and "democratic" (revolutionary) trends in Russian literature and criticism, which divided translators into two "ideological camps" - an extremely popular expression in Soviet translation studies. In the 1920s and 1930s, this division was only emerging, and translations seeking formal accuracy were not subjected to unconditional criticism. Alekseev describes different trends in the development of translation in the mid- $19^{\text {th }}$ century as being equal: "Translation efforts intensify again in the 1960s. Using translation for ideological propaganda, translators from the heterogeneous intelligentsia not only skillfully select the works they need from foreign literature - works that acquire a new meaning in the current Russian sociopolitical environment - but they also alter those texts with the same purposes in mind $\langle\ldots>$. However, in the same era, aristocratic writers with their inherent culture of foreign speech preserve the tradition of careful treatment of texts, going as far as protecting the principle of literal translation, as they are not interested in using foreign literature as a means of ideological propaganda and treat it as an object of pure aesthetic admiration" (Alekseev, 1934: 523-524). Following the current trend, the researcher also adds: "The application of this method resulted in heavy and inadequate literalism, with grammatical and metrical irregularities, incorrect accents, etc.” (Alekseev, 1934: 524).

We have to add that Alekseev never mentions this division of translators in his later works; however, it is picked up by other researchers, such as Zhinkin (1934: 141), Lann (1939) and others, and it quickly turns into a generally accepted ideological thesis of official Soviet translation studies. The division of translators into those from heterogeneous intelligentsia and those from aristocratic circles with their tradition of "careful treatment of texts" proposed by Alekseev develops into a division into the democratic (revolutionary) and the aesthetic (reactionist) "camps".

This division does have certain historical prerequisites, but studies on the history of Russian translation make it absolute and regard it as the only ideologically correct 
way of interpreting translators' activities and their translation principles. Even poor translations are regarded as particularly significant and progressive in terms of the development of the translation of literary works into Russian if their authors have democratic views. This is also why the activity of some translators (Mikhail Mikhaylov, Aleksey Pleshcheev, Dmitry Minaev, etc.) is analyzed more often, while the significance of the work of others (Afanasy Fet, Apollon Grigoryev, Apollon Maykov and others) is downplayed. Researchers pay special attention to revolutionary democrats' views on translation (Fedorov, 1968: 71-84, 57), even to their personal opinion on the subject, while detailed reasoning of other authors' translation principles is ignored or interpreted from an ideological perspective, revealing their "false" nature. As a result, some translation trends are presented as natural and "correct", while others are seen as incidental and "false". The very idea of the "correct" and "false" nature of trends is typical of the Soviet translation discourse and is based on ideology. This trend remains relevant until the $1980 \mathrm{~s}$.

Compared with the 1930s, Fedorov, the author of brilliant articles on translation, also significantly changes his views 30 years later. This is what he writes in the $1960 \mathrm{~s}-\mathrm{a}$ thesis that subsequently becomes a commonplace in Soviet studies on the history of the Russian translation: "The middle of the $19^{\text {th }}$ century was the time of a bitter ideological and political struggle in Russian literature, a struggle between writers from various social classes (raznochintsy), the bearers of revolutionary democratic principles, who believed that art was to serve the people, on the one hand, and representatives of the reactionary nobility and liberal intelligentsia who believed in 'art for the sake of art', on the other. This struggle left a peculiar mark on translation." (Fedorov, 1968: 67). P. Toper expresses similar ideas in a related conceptual paradigm, saying that "anti-realism" is equal to antipopular ideas: "The main struggle in the field of translation in the 1960s was the same as in any other creative field: the struggle between supporters of socially important, popular and realistic art - Chernyshevsky and Dobrolyubov's idea - and the antirealistic, antipopular movement of 'art for the sake of art"' (Toper, 1955: 81). Gachicheladze (1970: 30-31) interprets translation efforts of the mid-19 ${ }^{\text {th }}$ century in the same ideological vein. Gotsiridze and Khukhuni (1988: 134) use somewhat different terms, reducing the history of translation in the mid- $19^{\text {th }}$ century to a struggle between the "noble liberal and revolutionary democratic camps of Russian social thought."

This is where the rigid division of translators into two opposing "camps" takes root. All researchers who observe it mention pretty much the same names: the revolutionary democratic camp includes Aleksey Pleshcheev, Mikhail Mikhaylov, Vasily Kurochkin 
and Dmitry Minaev, with Afanasy Fet, Apollon Maykov, Karolina Pavlova and Aleksey Tolstoy in the reactionary noble camp. This division does indeed explain a number of facts in the history of Russian translation, especially in terms of the selection of works to translate. Fedorov is absolutely right to note: "Naturally, both camps had their own interests in foreign literature. Pleshcheyev and Mikhaylov, for instance, were among the first ones to translate Shevchenko, their contemporary and companion. In Heine's poetry (along with his love poems), they were attracted by works with social and political content, satire. Minaev translated Heine's epic poem Germany. A Winter's Tale and a revolutionary poem "The Silesian Weavers" <..., while Fet, Maykov and Mey turned to Heine's love poems or his historical ballads, with Fet also focusing on the individualistic and contemplative side of Goethe's philosophical poetry" (Fedorov, 1968: 67-68). However, even if representatives of the opposing camps had the same interests in the selection of poems to translate, "the translated material was interpreted and delivered in different ways, following the difference in their approaches towards the original" (Fedorov, 1968: 68).

Soviet studies on the history of Russian translations of literary works of the mid$19^{\text {th }}$ century recognize this approach as the only true one, and all the achievements of the Russian translation culture of this period are associated with the work of translators of the revolutionary democratic camp or even with critics who work within the framework of this approach. According to Staritsyna (1980: 79), "in the middle of the $19^{\text {th }}$ century, Russian translation culture reached an advanced stage, particularly thanks to the development of the theory of translation by such revolutionary democrats as Belinsky, Chernyshevsky and Mikhaylov. They put forward the need to select ideologically significant works, called for precise reproduction of ideological content, thoughts, the very spirit of the original and, in addition, for the observance of the form and stylistic features of the original." Appeals to such truisms (to convey the spirit and not the letter, to reproduce the form in conjunction with the content, to convey thoughts and stylistic features of a work, etc.) regarded as important achievements in the development of the theory of translation are not uncommon in Russian translation studies of the 1950s-1980s.

The study of the history of translation in the mid- $19^{\text {th }}$ century largely follows the initial ideological thesis about the opposition of different "camps" of translators. The ideology of the history of translation results in a biased interpretation of facts. For example, Afanasy Fet, Lev Mey and Aleksey Tolstoy - translators who use completely different methods, have different ideas about the "formal peculiarity of the original" and 
about the ways of its reproduction in translation - are put in one group. Researchers also overlook the fact that, compared to Lev Mey or Aleksey Tolstoy, Mikhail Mikhailov, a representative of the revolutionary democratic camp, has much tougher requirements to the formal correspondence between the translation and the original, particularly to the verse, rhyme, rhythm, and sometimes even to syntactic movement. On the other hand, Apollon Maykov, a representative of the reactionary noble camp (according to Fedorov) is one of the most liberal translators of the middle of the $19^{\text {th }}$ century. He not only does not seek to convey formal features of the original, but he also simply rewrites and adds them in his translations.

The desire to interpret the activity of translators from a given ideological perspective often results in biased views on specific translation practices, which, however, are built into the general ideological paradigm of socialist realism.

\section{$19^{\text {th }}$ century predecessors of 'realistic translation'}

The division of translators into "ideological camps" and the criticism of literalism as an attribute of the reactionary camp is supplemented in Soviet translation studies with the idea that a so-called "realistic translation" is emerging in Russia of the second third of the $19^{\text {th }}$ century. According to the ideology of the Soviet translation school, it is the precursor of the then-dominant realistic translation theory. This leads researchers to creating a model of the development of translation that follows the "classicism romanticism - realism" pattern typically used in literary and art criticism.

The concept of "realistic translation" is proposed by Kashkin $(1954,1955)$ as the most advanced translation principle that corresponds to the method of socialist realism. Kashkin's ideas are elaborated by Gachicheladze in his doctoral thesis and in several monographs, where he sets out the concept of realistic translation in the context of Lenin's theory of reflection: “... a realistic translator, following the laws of realism in art (the reflection of everything characteristic and typical in form and content, the re-creation of their unity) reflects the artistic substance of the original, and verbal, or rather stylistic, correspondences only help achieve authenticity, and do not impose their will" (Gachicheladze, 1980: 127).

Other researchers transpose the notion of "realistic translation" into the history of translation. At first glance, it is quite easy to do that, especially since both Russian and foreign literary critics repeatedly talk about principles of classical and romantic translation. Mikushevich attempts to distinguish classical, romantic and realistic translation by interpreting their "poetic motive" - a concept proposed and not 
fully clarified by the author of the article. According to V. Mikushevich, "realistic translation is the aesthetics of correspondences in action. Unlike a romantic one, a realistic translator does not reveal the poetic motive of the work in order to surpass the author on the way to the ideal. The task of realistic translation is to realize and reveal the relationship between the original and the potential in the original work, if the aesthetic experience reveals such a relationship. Realistic translation is aimed at revealing and capturing the artistic integrity of the original as a central correspondence in a particular series of cultural and historical correspondences" (Mikushevich, 1971: 50). The concept proposed by Mikushevich does not make it clear as to what specific phenomena he means by the definitions he puts forward.

Other researchers seek to identify specific typological features of the realistic translation of the mid- $19^{\text {th }}$ century. To name but a few, this strategy was used by Aznaurova (1955) and Toper (1955), who set realistic translation in opposition with reactionary and literal ones. Feeling the inadequacy of the term realistic translation and perhaps seeking to dissociate himself from Kashkin and Toper, Fedorov chooses the term truthful translation, linking it with the activities of Nikolay Chernyshevsky, Nikolay Dobrolyubov and Mikhail Mikhaylov. The essence of "truthful translation" is that it does not suggest "a mechanical transfer of a simple sum of individual elements of the original, but its reproduction as an artistic and ideological whole in relation to which individual elements perform this or that function $<_{\ldots} . .>$. The struggle for the truthfulness of translation meant the need to struggle, on the one hand, against any arbitrary actions of the translator ... and, on the other hand, against literalism and formalism" (Fedorov, 1960: 21).

Various authors are included in the ranks of realistic literary translators of the $19^{\text {th }}$ century. For instance, Etkind believed Alexander Pushkin to be the creator of realistic translation. He distinguished classical, romantic and realistic types of translation exemplifying it by three verse translations of prosaic texts: Vasily Trediakovsky's Telemachida (The Adventures of Telemachus by François Fénelon), Vasily Zhukovsky's Undina (Undine by Friedrich de la Motte Fouqué) and Alexander Pushkin's Songs of the Western Slavs (La Guzla by Prosper Mérimée) (Etkind, 1973: 241-242). The first translation is governed by the genre, the second one follows the translator's personal view of "his own ideal", and the third one is based on appreciation of national and historical background of the original. The researcher's theory does not account for the fact that a translator may be guided by not only an "idea", an "ideal" or an "imaginary original" but also by the text itself. Following Etkind's logic, one can arrive at 
paradoxical results. If, for example, a translator comes across expressions whose style does not correspond to the described period in a text by Walter Scott or encounters a folk song in a text by Shakespeare that does not correspond to the style of the nation in question (e.g. Danish), he must rework them in accordance with an "imaginary original" for the translation to be considered "realist".

Levin believes that Aleksandr Druzhinin and Irinarkh Vvedensky "took steps towards realistic translation": "Vvedensky's principle, and later on $<\ldots>$ Druzhinin's as well, involved a comparison of the stylistic systems of the two languages based on an analysis of historical and cultural traditions of the two nations in order to find functional correspondences and adequate means that would make the same impression on readers in a new language environment - this principle was realistic by nature. For realistic translation begins when a translator subordinates his work to what is now called comparative stylistics" (Levin, 1985: 127). The context of the research does not make it clear as to why the author's definition is exemplified by Druzhinin's translations that tone down Shakespeare's vibrant language and by Vvedensky's permissive "Russifying" translations (and not by Kurochkin's or Mikhailov's work, for instance).

We should also note that such definitions of realistic translation in Soviet translation studies traditionally use rhetorical figures that do not actually explain anything. Speaking of Druzhinin's translations, Levin emphasizes that any simplifications and stylistic leveling of a given text have but one goal: it is vital that the translation should "produce the same impression on Russian readers as the original does on English ones" (Levin, 1968: 17). Such psychologization of argumentation, i.e. the search for signs of "good" (that is to say, realistic) translation in the reproduction of the original's effect, is very common in Russian translation studies.

The importance of "realistic interpretation" of Shakespeare in Russian translations of the middle of the 19th century is repeatedly exaggerated in Russian translation studies as well. The fundamental collective study of Shakespeares' translations into Russian Shakespeare and Russian Culture (Alekseev, 1965) demonstrates that this thesis is in fact inadequate. Part five of this study is entitled "On the road to a realistic interpretation of Shakespeare", which leads the reader to expect that the next chapter on the $1860 \mathrm{~s}$, when efforts of the revolutionary democrats intensified, discusses the realistic interpretation of Shakespeare's works. However, this period in the development of Russian translations of Shakespeare is just chronologically designated as 'the sixties'. The next chapter on the 1870 s is called "In the spirit 
of realism" (Rovda), and it centers around translations by Shulgin, Danilevsky, Sokolovsky, Kholodkovsky, Gerbel, Kuskov, and others. The researcher rightfully believes that translations done "in the spirit of realism" tend to "make improvements" to Shakespeare's texts and to "even out" the original in terms of its vocabulary, style, meter and rhythm. They leave an impression of "taking Shakespearian poetry down to the level of trivial tastes of a philistine Russian reader" (Rovda, 1965: 561). Rovda also notes that "Despite the author's desire to make them close to the original and to convey its spirit, Shulgin's translations do not meet these conditions; the translator does not fully understand all the subtleties of the original and cannot impart a stylistic unity to his translation" (Rovda, 1965: 557); "The most interesting and notable figure among Shakespeare's translators $<\ldots>$ was Sokolovsky, who had previously translated Shakespeare for Nekrasov and Gerbel's publication. $<\ldots>$ Despite his enormous work, Sokolovsky's translations did not become a significant milestone in the exploration of Shakespeare's works..." (Rovda, 1965: 557). The notion of "realistic translation" acquires a more specific, although still rather vague, meaning in opposition with the concept of literalism. Therefore, Rovda concludes that Sokolovsky is "an enemy of literalism". This opposition allows us to see some of the merits of his translations. Thus, either realistic translations of Shakespeare do not coincide in time with realistic interpretation of his texts or they represent the most lackluster part of Shakespeare's translations into Russian.

In his polemic with Levin in the 1970s, Shor proposes a typological, as opposed to a historical, interpretation of translation. He expresses doubts about the effectiveness of drawing parallels between the history of translation and the history of original literature, and he uses concrete facts to prove the inconsistency of the "classicism romanticism - realism" pattern when applied to translated literature (Shor, 1973: 283). Etkind is critical of Kashkin's "curious theory" (Etkind, 1959: 133).

Studies published in the 1990s criticize ideological stereotypes in Russian translation studies. For example, Nelyubin and Khukhuni note that "The desire to fully align translation efforts with ideological aspects of the literary life of the era in question (1860s - A.A.) was particularly clearly manifested in a number of Soviet works, especially those written before the middle of the 1950 s $<\ldots>$. However, since it was obvious that contrasting "good" revolutionary democratic translations with "bad" noble liberal ones was one-dimensional and in some cases downright absurd, this theory was essentially forgotten a few decades ago..." (Nelyubin \& Khukhuni, 1999: 
79-80). The analysis above shows that, in fact, the theory did remain relevant in the $1960 \mathrm{~s}$, the 1970s, and even in the 1980s.

Studies of the 1990s no longer find the division of translators into "ideological camps" relevant; nevertheless, a number of ideologemes continue to exist in a new form. For instance, literalism is still viewed as a translation practice based on "false" translation principles. Translators of the $19^{\text {th }}$ century are no longer criticized for selecting works that have nothing to do with public issues. Toper reconsiders his position to some extent: in his study published in 2001, he does not classify translators on an ideological basis; nevertheless, he still makes negative demagogical comments on literal translation in general and on Fet's translations in particular: "Of course, this is not about the lack of talent in general, but about false views on translation or, to essentially rephrase the same idea, it is about a mediocre translation talent..." (Toper, 2001: 99). Overall, it can be argued that the search for predecessors of the $19^{\text {th }}$-century realistic translation has ideological underpinnings in Soviet translation studies. This approach leads researchers to creating a model of the development of translation that follows the "classicism - romanticism - realism" pattern, which is typically used in literary and art criticism and corresponds to the ideology of the Soviet school of translation.

\section{Conclusion}

The predominant trend in Soviet translation studies is to ideologize the history of Russian translation of the $19^{\text {th }}$ century, which leads to the division of translators into opposing "ideological camps" ("democratic" and "aesthetic"), which are guided, respectively, by "correct" and "false" translation principles. This interpretation results in biased judgments on certain translation practices and on the work of some translators. The choice of works to be translated is also determined by ideology. Focusing on the foreign text is declared a "false" strategy, and the only "correct" way to go about a translation is catering for its readers' stylistic preferences in order to make original works available to a mass readership. This results in researchers following a simplified historical and literary interpretation of the history of translation in Russia, where the development of literary translation boils down to the traditional pattern of "classicism - romanticism - realism". Researchers offer various interpretations of the notions of "romantic" and "realistic" translation, and this opposition finds meaning in the contrast between "false" and "correct" principles employed by translators from the democratic (revolutionary) and aesthetic (reactionary) "ideological camps". 


\section{References}

Alekseev, M.P. (1934). Istoriia perevoda v Rossii [The history of translation in Russia], In Literaturnaia entsiklopediia [Literary encyclopedia], Moscow: Sovetskaia entsiklopediia, 8, 521-526

Alekseev, M.P. (ed.) (1965). Shekspir i russkaia kultura [Shakespeare and Russian culture], Moscow-Leningrad, 824 p.

Aznaurova, E.S. (1955) Stanovleniie realisticheskikh traditsii russkogo hudozhestvennogo perevoda [The formation of realistic traditions of the Russian literary translation]. Author's abstract of the dissertation for the degree of a candidate of philological sciences, Moscow, 18 p.

Azov, A. (2013). Poverzhennyie bukvalisty. Iz istorii khudozhestvennogo perevoda $v$ SSSR v 1920-1960-e gody [Defeated Literalists. From the history of literary translation in Russia in 1920s-1960s]. Moscow: Vysshaia shkola ekonomiki, 299 p.

Etkind, E.G. (1959) Perevod i sopostavitelnaia stilistika [Translation and comparative stylistics], In Masterstvo perevoda [Mastery of translation], Moscow, Sovetskii pisatel, 71-86

Etkind, E.G. (1973). Russkiie poety-perevodchiki ot Trediakovskogo do Pushkina [Russian poets-translators from Trediakovsky to Pushkin]. Leningrad, Nauka, 1973, 247 p.

Gachicheladze, G.R. (1970). K istorii khudozhestvennogo perevoda v Rossii [To the history of literary translation in Russia], In Gachicheladze, G.R. Vvedeniie v teoriiu khudozhestvennogo perevoda [Introduction to the theory of literary translation], Tbilisi, 26-42.

Gachicheladze, G.R. (1980). Hudozhestvennyi perevod i literaturnyie vzaimosviazi [Literary translation and literary interrelations]. Moscow, Sovetskii pisatel, $256 \mathrm{p}$.

Gotsiridze, D.Z., Khukhuni, G.T. (1988). Ocherki po istorii zapadnoevropeuskogo $i$ russkogo perevoda [Essays on the history of Western European and Russian translation]. Tbilisi, The Tbilisi University Publishing House, 252 p.

Chukovsky, K.I. (1988). Vysokoie iskusstvo [The high art]. Moscow, Sovetskii pisatel, $352 \mathrm{p}$.

Chukovsky, K.I. (1936). Iskesstvo perevoda [The art of translation]. MoscowLeningrad, ACADEMIA, 228 p.

Fedorov, A.V. (1928). Zvukovaia forma stikhotvornogo perevoda (Voprosy metriki i fonetiki) [The sound form in verse translation (The questions of metrics and poetics)], In Poetika, Leningrad, ACADEMIA, 45-69. 
Fedorov, A.V. (1960). Russkie pisateli i problemy perevoda [Russian writers and the problem of translation], In Russkie pisateli o perevode [Russian writers on translation], Leningrad, Sovetskii pisatel, 6-27.

Fedorov, A.V. (1968). Osnovy obshchei teorii perevoda [Foundations of the general translation theory]. Moscow, Visshaia shkola, 396 p.

Inggs, J. (2015). Translation and transformation: English-language children's literature in (Soviet) Russian guise, In International Research in Children's Literature, 8, 1-16.

Baer, B. J. (2016). Translation and the Making of Modern Russian Literature. New York, Bloomsbury, 213 p.

Kashkin, I.A. (1954). O metode i shkole sovetskogo hudozhestvennogo perevoda [On method and school of the Soviet literary translation], In Znamya, 10, 148-157.

Kashkin, I.A. (1955). V bor'be za realisticheskij perevod [The struggle for realistic translation], In Voprosy hudozhestvennogo perevoda [The questions of literary translation], Moscow, Sovetskii pisatel, 58-94.

Khomitsky, M. (2013). World literature, Soviet style: A forgotten episode in the history of the Idea, In Ab Imperio, 3, 119-154.

Lann, E. (1939). Stil' rannego Dikkensa i perevod "Posmertnyh zapisok Pikvikkskogo kluba"[The style of early Dickens and the translation of "The Posthumous Papers of the Pickwick Club'], In Literaturnii kritik [Literaturny kritik], 1, 157-158.

Levin, Iu.D. (1968). Russkiie perevody Shekspira [Russian translations of Shakespeare], In Masterstvo perevoda [Mastery of translation], Moscow, Sovetskii pisatel, 5-25.

Levin, Iu.D. (1985). Russkie perevodchiki XIX veka [Russian translators of the $19^{\text {th }}$ century]. Moscow, Nauka, 299 p.

Mikushevich, V.B. (1971). Poehticheskii motiv i kontekst [Poetic motive in context], In Voprosy teorii hudozhestvennogo perevoda [The questions of literary translation], Moscow, Khudozhestvennaia literatura, 6-79.

Neliubin, L.L., Huhuni, G.T. (1999). Istoriia i teoriia perevoda v Rossii [The history and theory of translation in Russia]. Moscow, Narodnyi uchitel, 139 p.

Rovda, K.I. (1965) Pod znakom realizma. Gody reakcii [Under the sign of realism. Years of reaction] In M.P. Alekseev (ed.) Shekspir I russkaia kultura [Shakespeare and Russian culture], Moscow-Leningrad, 544-626.

Sherry, S. (2015). Discourses of regulation and resistance: Censoring translation in the Stalin and Khrushchev Era Soviet Union. Edinburgh University Press, 198 p. 
Shor, V.E. (1973). Kak pisat istoriiu perevoda? [How to write a translation history?], In Masterstvo perevoda [Mastery of translation], 6, Moscow, Sovetskii pisatel, 277-295.

Staritsyna, Z.A. (1980). Beranzhe v russkom literature [Beranger in Russian literature]. Moscow, Visshaia shkola, 188 p.

Toper, P. M. (1955). Traditsii realizma [Traditions of realism], In Voprosy literaturnogo perevoda [The questions of literary translation], Moscow, Sovetskii pisatel, 67-98.

Toper, P.M. (2001). Perevod v sisteme sravnitelnogo literaturovedeniia [Translation in the system of comparative literary studies]. Moscow, Naslediie, 254 p.

Witt, S., Baer, B. J. (eds.). (2017). Translation in Russian Contexts: Culture, Politics, Identity. London, Routledge, 350 p.

Witt, S. (2016). Socialist Realism in Translation: The Theory of a Practice, In Baltic Worlds, IX:4, 52-58, Available at: http://balticworlds.com/wp-content/uploads/2017/02/ BW-4-2016-23-82.pdf.

Vitt, S. [Witt, S.]. (2017). The Soviet school of translation - to the history of the concept, In Translation Strategies and State Control. Lea Pild (ed.), In Acta Slavica Estonica, IX, Tartu, Tartu University Press, 36-51.

Witt, S. (2017). Institutionalized intermediates: Conceptualizing Soviet practices of indirect literary translation, In Translation Studies, 10 (2), 166-182.

Witt, S. (2013). Arts of Accommodation: The First All-Union Conference of Translators, Moscow, 1936, and the Ideologization of Norms, In The Art of Accommodation. Literary Translation in Russia, L. Burnetta, E. Lygo (eds.), Peter Lang Publishing Group, Oxford, 41-184.

Zhinkin, N.P. (1934). A.K. Tolstoi i G. Geine [A.K.Tolstoy and H. Heine], In Sbornik statei k sorokaletiiu uchenoi deyatelnosti akademika A.S. Orlova [A collection of article for the fortieth anniversary of the activity of academician A.S. Orlov], Leningrad, The Academy of Sciences of the USSR, 1934, p. 433-441. 


\title{
Идеологизация истории перевода: на примере русской демократической и эстетической школ
}

\author{
А.В. Ачкасов \\ Российский государственный педагогический \\ университет им. А. И. Гериена \\ 191186, Санкт-Петербург, набережная реки Мойки, д. 48
}

Одной из ключевых тем советской школы перевода 1930-1960-х годов были «ложные» приниипь формализма и буквализма и продвижение реалистического перевода. $\mathrm{B}$ статье показано, что эта дискуссия была ретроспективно перенесена на литературный перевод ХІХ века, что привело к идеологизачии истории перевода. В результате практика перевода ХІХ века осмыслялась как противостояние эстетического (реакиионного) и демократического (револючионного) переводческих «лагерей», которые руководствовались, соответственно, «ложными» и «правильными» принципами перевода. Исследования советского периода по истории литературного перевода признавали такой подход единственно верным с связывали достижения литературного перевода середины ХІХ века с «революиионным демократическим лагерем» переводчиков и демократической школой критики. В рамках указанного подхода исследовали упорно искали среди переводчиков ХІХ века предшественников реалистического перевода, который мыслился как аналог социалистического реализма. Согласно такой интерпретации самые разные переводчики ХІХ века объявлялись предтечами советской школь реалистического перевода и была создана модель истории перевода, которая соответствовала традиционной для советской критики схеме «классииизм-романтизм - реализм». Исследователи предлагали разные интерпретации понятий «романтический» и «реалистический» перевод, однако эта оппозиция приобретала реальный смысл только в рамках противопоставления «ложных» $и$ «правильных» принципов представителей демократической и эстетической идеологий. В статье показано, что эта тенденция соответствовала идеологической парадигме социалистической литературной теории и интерпретации истории искусства в целом.

Ключевые слова: история перевода; идеологизация; советская школа перевода; буквализм; реалистический перевод; демократь;; эстетьл.

Научная специальность: 10.00.00 - филологические науки. 